\title{
КОКСАРТРОЗ: ВАРІАНТИ ЛІКУВАННЯ НА РІЗНИХ СТАДІЯХ ХВОРОБИ
}

\author{
Н. В. Мороз, О. I. Зарудна \\ Сумська обласна клінічна лікарня \\ ДВНЗ «Тернопільський державний медичний університет \\ імені І. Я. Горбачевського МОЗ України" \\ ННІ медсестринства
}

У статті наведено епідеміологічні дані, причини, діагностику коксартрозу та переглянуто методи лікування на різних стадіях хвороби.

\section{COXARTHROSIS: VARIANTS OF THE TREATMENT ACCORDING TO THE STAGE OF THE DISEASE}

\author{
N. V. Moroz, O. I. Zarudna \\ Sumy Regional Clinical Hospital \\ SHEI «Ternopil State Medical University by I. Ya. Horbachevsky of MPH of Ukraine» \\ Educational and Scientific Institute of Nursing
}

\footnotetext{
The article deals with epidemiological data, causative factors, diagnostic of coxarthrosis. There is presented the review of treatment according to the stage of the diseases.
}

Вступ. У структурі дегенеративно-дистрофічних захворювань суглобів коксартроз займає одне з провідних місць. Це хвороба, яка характеризується порушенням кровообігу в суглобі, деформацією і руйнуванням його елементів. Може перебігати у вигляді одностороннього ураження та двобічного процесу. Коксартроз уражає людей середнього, старшого та похилого віку, велика частина з яких $є$ працездатними та соціально активними. Тому використання ефективних методів лікування, в тому числі хірургічних (тотального ендопротезування), $\epsilon$ надзвичайно важливим для підтримання якості життя пацієнтів.

Основна частина. Остеоартрозом страждає кожен п'ятий житель планети [1], причому це захворювання $\epsilon$ найчастішим серед патологі опорно-рухового апарату в різних регіонах земно кулі [2, 3]. Хвороба несе велике медичне, соціальне та економічне навантаження на суспільство [4]. Найбільш актуальною вважається проблема уражень колінних і тазостегнових суглобів, оскільки гонартроз і коксартроз $\epsilon$ найбільш інвалідизуючими локалізаціями пато-

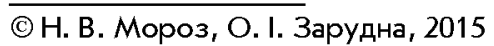

логічного процесу [5]. Кожний четвертий ортопедичний хворий страждає захворюваннями суглобів, серед яких більш ніж $60 \%$ становлять люди працездатного віку, а у 11,5 \% це призводить до інвалідизаці. Останнім часом відзначається тенденція до зростання захворюваності на коксартроз серед осіб молодого віку. Коксартроз - це один із різновидів артрозу, який уражає кульшові суглоби. Це захворювання спостерігається при анатомо-функціональній неповноцінності опорно-рухового апарату, зумовленого вродженими порушеннями розвитку, травмами, перенесеними запальними процесами й іншими порушеннями [6].

Виділяють такі причини розвитку коксартрозу:

- тривале навантаження на суглоб, його перевантаження (наприклад: у спортсменів, або людей $з$ надмірною масою);

- травмування суглоба (навіть у молодих людей травмування може призвести до розвитку коксартрозу);

- артрит (запалення суглоба) часто $є$ причиною виникнення коксартрозу;

- цукровий діабет, порушення обміну речовин, гормональні зміни тощо також можуть бути причинами виникнення коксартрозу. 
Тяжкість симптоматики коксартрозу зростає відповідно до ступеня.

Коксартроз І ступеня (рання стадія). Періодично виникає біль в ділянці суглоба. Біль з'являється, як правило, тоді, коли пацієнт після спокійного стану починає рухатися. Суглоб «розробляється», біль вщухає. У стані спокою біль не відчувається. Суглоб рухливий, як у здорово людини. Рентген показує лише незначні розростання кісткових тканин, майже непомітне звуження суглобово щілини, головка і шийка стегново кістки не змінені.

Коксартроз II ступеня. Біль починає іррадіювати в коліно і стегно. Виникає і в стані спокою. При інтенсивних фізичних навантаженнях (тривала хода, біг) хворий починає мимоволі кульгати. Зміни, видимі рентгеном, стають більш помітними: деформується головка стегново кістки,

контур стає нерівним, шийка кістки потовщена, суглобова щілина звужена на одну третину від норми.

Коксартроз III ступеня. Біль стає перманентною, хворий відчуває незалежно від навантажень, вона може стати причиною безсоння. Рухливість в суглобі настільки обмежена, що хворий не може ходити без підтримки. Рентген показує значне зменшення суглобово щілини, шийка стегново кістки дуже широка і коротка, порівняно $з$ нормою, головка стегново кістки деформована.

Діагноз коксартроз встановлюється на підставі:

- особистого огляду пацієнта (що дозволяє визначити напрямки подальших досліджень);

- клінічних аналізів: загальний і біохімічний аналізи крові (за $\mathrm{x}$ допомогою можна визначити наявність в організмі запальних процесів, можна відрізнити артрит від артрозу);

- рентгенографія дозволяє побачити пошкодження та зміни кісткових тканин (недолік - не можна оцінити стан м'яких тканин або рідких структур); натомість - МРТ суглоба $є$ дуже ефективним способом, що дозволяє побачити навіть незначні зміни хрящів.

У кожному випадку лікування підбирається індивідуально залежно від стаді захворювання, віку пацієнта, супутніх захворювань. Лікувальні процедури можуть включати консервативні та медикаментозні методи. Призначення нестеро дних (тобто негормональних) протизапальних засобів. Вони знімають біль. Вони використовуються на будь-якій стаді коксартрозу.

ЕФективним $є$ призначення засобів, що знімають м'язове напруження навколо суглоба - міорелаксантів. Вони знімають біль і покра- щують кровообіг у ділянці суглоба. Благоприємним для перебігу захворювання $є$ призначення засобів, які відновлюють хрящову тканину (хондро тин сульфат, глюкозамін). Ця медикаментозна група $\epsilon$ найбільш ефективною у випадку тривалого та правильного застосування і збалансованого поєднання $з$ лікувальною фізкультурою та методами фізіотерапі .

Фізіотерапія: електрофорез, фонофорез, кріотерапія, лазерна терапія. Всі вони спрямовані на поліпшення кровообігу в ураженій частині та зняття запалень. Апаратне витягування суглоба застосовується для того, щоб зменшити навантаження на поверхні суглоба. Виконується за допомогою спеціального обладнання. Таке лікування $є$ курсовим. Існує витягування м'язів і зв'язок без застосування допоміжних механізмів (постізометрична релаксація). Пацієнт активно працює, також як і лікар. Завдання пацієнта - розслабляти і напружувати певні групи м'язів. Лікар виконує розтяжку в моменти розслаблення.

На початкових стадіях лікування дозволяє призупинити розвиток хвороби. Вчасно розпочавши - пацієнт ніколи не дізнається, що це таке - коксартроз III ступеня.

На базі КЗ “СОКЛ" ретроспективно проаналізовано результати 30 операційних втручань виконаних протягом 2012 року шляхом тотального ендопротезування кульшових суглобів у хворих на коксартроз.

Вік хворих коливався від 35 до 77 років. Жителі м. Суми складали 56 \% прооперованих, інші $44 \%$. Під час ендопротезування використовували ендопротези виробництва Укра ни з цементним типом фіксаці та США (Біомет та Страйкер) 3 цементним та безцементним типом фіксаці .

Протези з цементним типом Фіксаці застосовували у 9 (20\%) хворих літнього і старечого віку. Це зумовлено слабкістю кістково тканини, внаслідок остеопорозу. Крім того, цементний тип фіксаці протеза дозволяє раннє навантаження на оперовану кістку, що вкрай важливо для хворих у цьому віці. Протези з безцементним типом фіксаці встановлювали 34 (80\%) хворим у більш молодому віці 3 добре збереженою кістковою тканиною.

Післяопераційний період перебігав без особливостей, проводилась рання активізація хворих.

Після операці ендопротезування кульшового суглоба перебування хворого на ліжку в середньому складає 8-10 днів. До цього часу відбувається загоєння післяопераційно рани, хворий вміє ходити на милицях на невеликі 
відстані, обслуговує себе в побуті, але ще вимагає сторонньо допомоги. Транспортуватися хворий може в звичайному легковому автомобілі в напівлежачому стані. Госпіталізація в стаціонар у перші 1-1,5 місяці після операці не потрібна.

Період адаптаці складає перші 1-1,5 місяці після операці, відбувається адаптація організму до вживленого імплантата, на місці видалено капсули суглоба утворюються рубцеві тяжі, розсмоктується післяопераційна гематома. По прибуттю додому від хворого вимагається виконання таких рекомендацій:

- ходьба на милицях не наступаючи на оперовану кінцівку (профілактика тромбоемболічних ускладнень, пролежнів, пневмоній та ін.);

- лікувальна фізкультура прооперовано кінцівки - регулярне виконання 3-х будь-яких вправ, спрямованих на зміцнення м'язів стегна насамперед чотириголового.

Щодо вправ:

- згинання ноги в колінному суглобі до 70$80^{\circ}$ і розгинання до рівного положення, при цьому п'ята стопи не відривається від постелі;

- під ногу в ділянці підколінно ямки підкладається валик або подушка висотою 25-40 см, виконується розгинання колінного суглоба до рівного положення за рахунок підняття гомілки і стопи;

- розгинання колінного суглоба в положенні хворого сидячи на краю ліжка («удар по м'ячу»).

Рекомендовано займатися вправами 6-8 разів на добу починаючи з $10-20$ разів за підхід із поступовим збільшенням навантаження (до 30 дня після операці - по 50-70 разів кожно вправи). Потрібно відзначити, що регулярні й систематичні заняття лікувальною фізкультурою $\epsilon$ запорукою швидкого відновлення працездатності хворих. Через 2-3 тижні від початку за-

\section{ЛITEPATУРA}

1. Wang $M$. Recent progress in understanding molecular mechanisms of cartilage degeneration during osteoarthritis / M. Wang, J. Shen, H. Jin, H. J. Im. // Ann. NY Acad. Sci. - 2011. - Vol. 1240, № 12. - P. 61-69.

2. Marhadour T. Osteoarthritis epidemiology and risk factors / T. Marhadour, D. Guellec, A. Saraux [et al.] // Soins. - 2012. - Vol. 768, № 9. - P. 28-29.

3. Tangtrakulwanich B. Epidemiology and risk factors of patellofemoral osteoarthritis in adults: a populationbased study in southern Thailand / B. Tangtrakulwanich, P. Suwanno // J. Med. Assoc. Thai. - 2012. - Vol. 95, № 8 . - P. 1048-1052. нять можна приступити до найбільш значимо вправи - підняття прямо ноги без згинання в колінному суглобі. Крім того, ця вправа $є$ критерієм оцінки наполегливості хворого в заняттях - якщо воно виконується з легкістю, значить лікувальній фізкультурі приділялося досить часу й уваги.

Бинтування нижніх кінцівок еластичним бинтом виконується протягом 1 місяця після операці з метою механічно профілактики тромбоемболічних ускладнень.

Повноцінне харчування - невід'ємна частина відновлення організму після тяжко операці. 3 метою лікування анемі рекомендується вживання м'ясних продуктів, Фруктів і овочів, з метою профілактики остеопорозу - молочних продуктів. 3 огляду на змушений тимчасовий малорухомий спосіб життя рекомендується відмовитись від хлібо-булочних виробів і солодощів.

Медикаментозне лікування полягає в прийманні лише рекомендованих лікарем препаратів кальцію, препаратів, що пригнічують резорбцію кістково тканини, медикаментів, які поліпшуючих периферійний кровообіг.

3 огляду на те, що хода на милицях викликає перевантаження протилежного кульшового суглоба, то при двосторонньому коксартрозі настає загострення болю у ньому, що вимагає приймання знеболювальних препаратів.

Висновок. На сьогодні для оптимізаці лікування хворих на коксартроз насамперед визначається його стадія, відповідно до яко складається лікувальний план. Рання діагностика та адекватна терапія попереджує інвалідизацію пацієнтів. Проте на пізніх стадіях хвороби для покращення якості життя пацієнта - виконання тотального ендопротезування $\epsilon$ найкращим вибором, що усуває біль, кульгавість, відновлює функцію опори та ходи уражено кінцівки.

4. HarrisHayes M. Relationship of acetabular dysplasia and femoroacetabular impingement to hip osteoarthritis: a focused review / M. HarrisHayes, N. K. Royer / / PMR. 2011 . - Vol. 3, № 11. - P. 1055-1067.

5. Michon F. Osteoarthritis. A public health problem / F. Michon / / Soins. - 2012. - Vol. 768, № 9. - P. 27-28.

6. Диагностика и печение дегенеративно-дистрофических поражений суставов / [И. В. Шумада, О. Я. Суспова, В. И. Стецула и др.] .- К : Здоровья, 1990. - 197 с.

Отримано 24.02.15 